\title{
V Interdyscyplinarna Międzynarodowa Konferencja Naukowa „Język religijny dawniej i dziś (w kontekście teologicznym i kulturowym)" oraz I Międzynarodowa Studencko-Doktorancka Konferencja Naukowa „Język religijny dawniej i dziś w oczach młodych badaczy"
}

20-22 września 2010 roku w Gnieźnie odbyła się kolejna konferencja z cyklu ,Język religijny dawniej i dziś (w kontekście teologicznym i kulturowym)", organizowana przez Zakład Gramatyki Współczesnego Języka Polskiego i Onomastyki UAM, Wydział Teologiczny UAM, Wydział Filologiczno-Filozoficzny Poznańskiego Towarzystwa Przyjaciół Nauk przy współpracy Komisji Języka Religijnego PAN.

Jednym $\mathrm{z}$ tematów przewodnich były religijne aspekty piśmiennictwa związanego z „Solidarnością” i innymi ruchami społecznymi, co podyktowane było chęcią uczczenia trzydziestej rocznicy powstania NSZZ „Solidarność”. Tematyka ta wyraźnie uwidoczniła się w prezentowanych tekstach, które ogniskują się wokół problemu ruchu „Solidarność” lub odnoszą się do początków ruchu solidarnościowego. Widać to między innymi w tytułach referatów: Rola religii i wiary w ruchu spolecznym „Solidarność” (prof. dr hab. Stanisław Mikołajczak), ,Solidarność” w pismach Jana Pawła II (prof. dr hab. Kazimierz Dopierała), Aktualność i znaczenie etyki solidarności Józefa Tischnera (ks. prof. dr hab. Paweł Bortkiewicz, s. dr Maria Krystyna Bogdan), Filmowe obrazy dławienia ,, Sierpnia”: polskie Pasje (ks. prof. dr hab. Marek Lis), Wideo $i$,Solidarność" - tematyka religijna w niezależnym filmie dokumentalnym lat 80. (dr hab. Mikołaj Jazdon).

Teksty rozpoczynające konferencję stanowiły zatem przypomnienie znaczenia i historii ruchów niepodległościowych, głównie „Solidarności” w historii Polski, których oddźwięk widoczny jest w różnego rodzaju tekstach kultury - również w filmie i innych sztukach wizualnych.

Kolejne wystapienia referentów ogniskowały się wokół problematyki szeroko rozumianego języka religijnego, na który referenci patrzyli nie tylko 
z perspektywy językoznawczej, literaturoznawczej, lecz również teologicznej i kulturowej. Problematyka języka religijnego w filmie pojawiła się na konferencji po raz kolejny i wywołała dyskusje o sposobach uobecniania się sacrum w filmach.

Ponadto swoistym novum tego spotkania były teksty, które pokazywały język religijny i jego elementy w sztukach plastycznych. Warto tu dla przykładu wskazać tytuły wystapień prof. dr hab. Renaty Rogozińskiej - Tylko pod tym znakiem. Ikonografia religijna w sztuce lat 80., prof. dra hab. Grzegorza Nowickiego - Elementy religijne pomników ,solidarnościowych”, mgra Stanisława Grześka - Elementy religijne na sztandarach NSZZ „Solidarność” czy dr inż. arch. Ewy Augustyn-Lendzion - Język architektury sakralnej. Wymienione teksty stanowiły swoiste dopełnienie kulturowego spojrzenia na język religijny.

Węższe rozumienie języka religijnego widoczne było w referatach językoznawczych, a także literaturoznawczych - nie tylko polskich badaczy. Niezwykle cenne w tej grupie były teksty prof. dr hab. Ewy Jędrzejko (Składnia jako wyznacznik przemian stylu kaznodziejskiego w XX wieku), ks. prof. dra hab. Wiesława Przyczyny (Funkcje homilii. Aspekt teologiczny), ks. prof. dra hab. Andrzeja Draguły (Zbawienie i marketing. Dwie strategie - jeden język) czy też phdr. Marceli Grygerkovej (Prvky náboženskè tematiky a jazyka cirkve $v$ řetězovỳch e-mailech (na českém materiálu) i doc. phdr. Karela Komarka (W sprawie opracowania języka pieśni religijnych).

Nowością, a zarazem próbą uaktywnienia młodych badaczy, była trwająca w tym samym czasie I Międzynarodowa Studencko-Doktorancka Konferencja Naukowa. Głównym organizatorem tej części spotkania było Koło Miłośników Języka UAM. Konferencja ta pokazała, iż badania nad językiem religijnym są atrakcyjnym polem badawczym zarówno dla studentów, jak i dla doktorantów z różnych ośrodków akademickich w Polsce. Wygłoszonych zostało 30 referatów. Podejmowane tematy pokazały w dużej mierze wrażliwość młodego badacza na przejawy współczesnego języka religijnego w różnego rodzaju mediach, czego ilustracją niech będą tematy wystąpień: Obecność Boga $w$ dyskursie parlamentarnym (Arkadiusz Piniarski), Czy seks jest święty? Język religijny a opisy wspótżycia seksualnego w mediach katolickich (Jagoda Rodzoch-Malek), Czy niebo to wieczny orgazm? Prowokacja jako swoistość języka religijnego Szymona Hołowni (Agnieszka Kowal), Marketing religijny. Slogan reklamowy w stużbie Kościoła (Beata Kłos).

Część tekstów jednak odnosiła się do dawnego języka religijnego, np. wystapienia: Anny Sality (Rola języka religijnego w ksztaltowaniu opozycji swój - obcy na przykładzie XIX-wiecznej prasy poznańskiej) czy Anny Lenartowicz (Przyblizenie świata a język Księgi Syracha (1535) w przekładzie Piotra Poznańczyka). 
Tematami podejmowanymi przez młodych badaczy były również zagadnienia dotyczące charakterystyki języka religijnego w wybranych tekstach, $\mathrm{w}$ tym poetyckich, prozatorskich, formach epistolarnych, tekstach kaznodziejskich, pieśniach młodzieżowych czy idiolekcie wybranego twórcy.

Ponadto uczestnicy obu konferencji mieli możliwość wzięcia udziału w warsztatach prowadzonych przez dra hab. Mikołaja Jazdona dotyczących rejestracji na wideo rozmowy przed kamera.

Uświetnieniem konferencji był koncert patriotyczno-religijny w katedrze gnieźnieńskiej Żeby Polska była Polska, nad którym patronat objął Jego Ekscelencja Ksiądz Arcybiskup Józef Kowalczyk Prymas Polski, Prezydent Miasta Gniezna Jacek Kowalski, Starosta Gnieźnieński Krzysztof Ostrowski, a także Przewodniczący Zarządu Regionu Wielkopolskiego NSZZ „Solidarność” Jarosław Lange. Wśród artystów wystapili soliści Teatru Wielkiego w Poznaniu (Tatiana Pożarska, Michał Marzec), a także aktorzy Teatru im. Aleksandra Fredry w Gnieźnie (Bogdan Ferenc, Andrzej Malicki) oraz chór „Polihymnia” z Poznania pod dyrekcją Tomasza Dzięcioła. 